\title{
Kuljemme yhdessä kohti älykästä organisaatiota
}

\section{Pentti Sydänmaan- lakka (2000), Älykäs organisaatio - Tiedon, osaamisen ja suorituk- sen johtaminen. Enter- prise Adviser - kirja- sarja KAUPPAKAARI OYJ}

\section{Millainen on älykäs orga- nisaatio?}

Älykäs organisaatio-kirja tarjoaa lukijalle ajatusmalleja ja kokemuksia siitä, miten organisaation, tiimien ja yksilöiden oppimista tuetaan, suorituksen parantamisesta huolehditaan, liiketoiminnan tavoitteita asetetaan, saadaan yhdessä aikaan tuloksia ja menestytään kansainvälisessä kilpailussa. Älykkäässä organisaatiossa osataan yhdistää pitkällä aikavälillä tehokkuus, jatkuva uudistuminen ja oppiminen sekä henkilöstön hyvinvointi. Pääosa kirjan sisällöstä käsittää johtamisen kolmen alueen laajaa käsittelyä ja pohdintaa: suorituksen johtaminen siten, että tavoitteena on jatkuva suorituksen parantaminen, osaamisen johtaminen ja sen kehittäminen sekä tiedon johtaminen niin, että pystytään luomaan uutta tietoa, hankkimaan, varastoimaan ja soveltamaan tietoa nopeasti päätöksentekotilanteissa. Kirjassa kuvataan monin tavoin, miten älykäs organisaatio oppii nopeasti, toimii tehokkaasti, uudistuu jatkuvasti ja pitää hyvää huolta omasta kilpailukyvystään, osaamisestaan ja henkilöstöstään. Kirjan kirjoittajan Sydänmaanlakan mielestä älykäs organisaatio on löytänyt tasapainon tehok- kuuden, oppimisen ja hyvinvoinnin välillä. "Jos asioita katsotaan liian lyhyellä perspektiivillä, haetaan tehokkuuttakin lyhytjänteisesti. Silloin saatetaan organisaatiota kehittää vain sokeiden markkinoiden, ei ihmisten ehdoilla. Organisaatio voi huonosti ja tehokkuus kärsii pitkällä aikajänteellä. Vaarana on ihmisten "burn out, joka on seurausta pelkän tehokkuuden tavoittelusta."

\section{Keskeinen sanoma läpi}

kirjan on, miten tulevaisuuden organisaatioissa voisimme toteuttaa suorituksen, osaamisen ja tiedon johtamisen prosessit ja miten voisimme yhdistää ne yhdeksi uudistetuksi suorituksen johtamisprosessiksi. Älykkään organisaation tulisi noudattaa toimintaohjetta: pelkistä, kiteytä, yksinkertaista, keskity olennaiseen ja näe kokonaisuuksia. Älykäs organisaatio on rakennettu ihmisiä varten eikä niin kuin nykyisin, että ihmisiä mukautetaan organisaatiota varten.

\section{Kirjan oppien mukaan}

meidän tulisi tehdä organisaatioista, joissa työskentelemme suuren osan elämästämme, ihanteellisia paikkoja tehdä työtä, olla yhdessä ja kasvaa kokonaisvaltaisesti ihmisinä. Tämä edellyttää syvällistä ajattelutapojen muutosta ja näin ollen meidän on rakennettava yhdessä uusi viitekehys, jonka avulla hahmotamme maailmaa ja näemme yksilön, tiimin ja organisaation roolin tässä kokonaisuudessa. Muuttuvassa toimintaympäristössä tarvitaan vallitsevien uskomusten ky- seenalaistamista ja uusien arvojen luomista. Ratkaisuna kirjassa esitetään useita ajatusmalleja ja sovelluksia, joista voisi oppia ja poimia itselleen ja organisaatiolleen uusia käytäntöjä ja kehityskohteita. Syvällinen pohdinta ja keskustelu organisaatiossa on tarpeen ennen kuin kirjan oppeja ja malleja aletaan yhdessä soveltaa käytäntöön.

\section{Monet niistä ovat}

kuitenkin tuttuja malleja ja sovelluksia, joita on tehty vuosien ajan ja yritetty soveltaa käytäntöön organisaatioissa - onnistumatta vielä pääsemään älykkään organisaation vaatimustasolle. Monet yritykset ja organisaatiot ovat vielä matkalla kohti älykästä tulevaisuuden ihannetilannetta tai kokevat sen vain hetkellisesti. Maailma muuttuu niin nopeasti. On pystyttävä toimimaan joustavasti ja kehittämään omaa osaamista ja järjestelmiä niin, että koko organisaatio, tiimit ja yksilöt saadaan mukaan ja hyväksymään jatkuva muutos ja kehittyminen. Voi olla, että mallien ja järjestelmien soveltaminen käytäntöön ei ole saanut kaikkia innostumaan ja sitoutumaan suorituksen johtamiseen, osaamisten kartoittamiseen ja kehittämiseen tai tiedon siirtämiseen muille, koska useimmat pitävät niitä henkilökohtaisina kilpailutekijöinä, joita ei haluta jakaa ja näyttää muille. Useimmat järjestelmät ja toimintamallit antavat vain viitekehyksen ja rutiinit ihmisten väliselle toiminnalle, jota voidaan toistaa vuodesta toiseen ilman 
näkyviä tuloksia ja parannuksia.

\section{Miten älykkäässä organi- saatiossa toimitaan}

Älykäs organisaatio-kirja esittää runsaasti toimintamalleja ja esimerkkejä, joiden avulla henkilöstölle voidaan luoda pysyviä edellytyksiä oppia ja onnistua työssään sekä koko organisaatiolle parempia mahdollisuuksia tehdä hyvää tulosta ja parantaa jatkuvasti suoritustaan. Samalla vahva usko ja mallintaminen suorituksen johtamiseen, osaamisen johtamiseen ja tiedon johtamiseen tekevät näistä jaksoista raskaita ja jäykkiä, joita esimerkitkään eivät juuri kirkasta, ellei satu tuntemaan kyseisiä yrityksiä lähemmin. Nokia on meille useimmille tunnettu "brändi" oman kännykkämme kautta, mutta se on yrityksenä poikkeuksellinen toimialansa, sen kasvun ja globaalisuutensa takia. Kirjoittajan henkilökohtaiset Nokiaajan kokemukset ja esimerkit ovat antoisia henkilöstöjohtamisen arkiselta saralta, jossa voi tapahtua melkein mitä tahansa. Myös Nixdorf/ Siemens'in palveluksessa ulkomailla työskentely opetti kirjoittajaa näkemään eri yrityskulttuurien väliset erot ja vaikeudet sopeutua siihen yritysten integrointivaiheessa. Jokainen tekee omat virheensä ja hankkii oppinsa menemällä tilanteeseen avoimesti joko esimiehen tai alaisen asemassa.

\section{Muista yritysesimerkeistä} on kirjaan valittu hyvinä esimerkkeinä Yleisradio (ydinosaamiset), VTT (henkilöstöjohtamisen toimintamalli) ja Suomen ICL (osaamisen kehittäminen). Suomen ICL'n osaamisen kehittämisen malli on hyvä tytäryhtiösovellus osaamisen kehittämiseksi ja sen hallintaan, joka on mille tahansa organisaatiolle erittäin tärkeä menestystekijä. Suomessa sovellettua toimintamallia ei kuitenkaan ICL'ssä käytetä laajemmin koko konsernissa, vaan pääasiassa myynnin, palvelu- ja projektitoiminnan alueilla sekä valituilla teknisen osaamisen alueilla. YLE ja VTT edustavat omalla julkisen palvelun alueellaan huippuosaamista ja pyrkivät parantamaan toimintaansa systemaattisesti joko osaamisen kehittämisen tai järjestelmien parantamisen avulla. Molemmissa on tavoitteena johtamisen tehokkuuden lisääminen ja pitkän tähtäyksen kehittäminen, jotka samanaikaisesti toteutettuna eivät ole helppoja. VTT on saanut yleistä tunnustusta työstään.

\section{Kirjan läpitunkeva}

sanoma on muutoksen nopeus ja jatkuva uudistuminen, joiden avulla ratkaistaan menestyminen kilpailussa. Älykkäässä organisaatiossa johtamisprosesseja on vähän, ne ovat yksinkertaisia ja kokonaisvaltaisen pelkistettyjä. Kaikkien tulisi sisäistää yhteinen visio, koska silloin voidaan valtaa ja vastuuta jakaa ja tehdä itsenäisiä päätöksiä. Kun suoritusta johdetaan hyvin, jokainen tietää tehtävänsä ja tavoitteet, joiden perusteella suoritusta arvioidaan ja siitä annetaan riittävästi palautetta.

\section{Osaamisen kehittäminen menestystekijänä}

Kirjassa esitetään väite, että osaaminen on organisaation eloonjäämisen ehto! Osaami- nen, jonka kehittämisestä organisaation tulee jatkuvasti huolehtia, luo toisaalta turvallisuutta ja toisaalta se on yritykselle tärkeä menestystekijä. Kysymyksiä on useita ja niihin kirjassa esitetään muutamia havaintoja ja oivalluksia.

- Ydinosaamislähestymistapa edellyttää syvällistä ja pitkäaikaista organisaation tuntemusta, koska joudutaan pohtimaan organisaation olemassaolon peruskysymyksiä.

Strategisen johtamisen perusasioita on hyvä ymmärtää, koska osaamisen johtamiseen perustuva ajattelumalli pohjautuu osaamisstrategioiden käytäntöön viemiseen.

- Osaamisen johtamisen vieminen käytäntöön on pitkä prosessi, jota toistetaan vuosittain. Se on myös oppimisprosessi, jonka aikana tulokset paranevat ja kehittyvät koko ajan.

- Osaamisen johtaminen yhdistää strategiaprosessin suorituksen johtamiseen, koska strategiasta johdetut osaamisen kehittämishaasteet viedään yksilötasolle.

Johdon tärkein tehtävä on hankkia, ylläpitää ja kehittää organisaation osaamista.

Organisaation pitää tukea yksilöiden uusiutumista.

- Johtamisen tulee olla osallistavaa ja pyrkiä siihen, että kukin voi johtaa itseään.

Yrityksen henkilöstöön sidottu henkinen pääoma muodostaa tärkeän osan kokonaispääomasta, jota on pystyttävä mittaamaan ja raportoimaan julkisesti esimerkiksi henkilöstötilinpäätöksen muodossa.

\section{Unelmia ja suosituksia}

Kirjan lopussa käsitellään tule- 
vaisuuden ihanneorganisaatiota, joka kirjoittajan mielestä on tehokas, oppiva ja hyvinvoiva. Se on myös älykäs ja sillä on kyky jatkuvasti uusiutua ja ennakoida muutoksia. Organisaation oppiminen on nopeampaa kuin ympäristön muutokset ja tällä tavoin se johtaa muutosta. Henkilöstö on organisaation tärkein resurssi ja sen takia se on rakennettu henkilöstön hyvinvointi huomioiden. Kirjoittajan mukaan mielessä on koko ajan pidettävä ihanneorganisaatio ja mietittävä sitä, miten sitä kohti voidaan mennä yksinkertaisin, selkein askelin. Haaveita ja unelmia tarvitaan, koska niistä syntyvät visiot.

\section{Kirjoittaja itse otti}

vuoden sapattivapaan kirjoittaakseen ajatusmalliensa, kokemustensa ja unelmiensa mukaisen kirjan, jota voi suositella yrityksen strategisten asioiden vastuuhenkilöille, johdolle, henkilöstön kehittäjille, konsulteille ja opettajille, joiden pitäisi kertoa organisaatioiden toimintamalleista ja tulevaisuuden suuntaviivoista. Oppikirjaksi en tohdi kirjaa suositella, koska sen mallit ja ohjeet ovat monimutkaisia ja vaikeita viedä sellaisenaan käytännön ohjelmiksi. Jotkut unelmista saattavat joskus toteutua, jos uskoo asiaansa ja yrittää niitä pitkäjänteisesti toteuttaa omassa organisaatiossaan niin, että johto on sitoutunut suorituksen, osaamisen ja tiedon johtamisen toteuttamiseen systemaattisesti, tiimit osallistuvat näihin toimintoihin ja yksilöt kokevat saavansa siitä osansa parempina suorituksina, hyvinä osaamisina ja oikeina, tarvittavina tietoina oikeaan aikaan. Useimpien meistä on edelleen jatkettava päivittäistä puurtamista ja suoriutumista niistä monista tehtävistä, joihin meillä on tarvittavat kyvyt, henkilökohtainen kokemus ja ominaisuudet.

Veikko Sipola 